\title{
Sources of Information on Flood-Resistant Design and Construction ${ }^{1}$
}

Regina Fegan and Micahel T. Olexa ${ }^{2}$

The primary purpose of the publications referenced in this article is to assist engineers, architects, contractors, and property owners in locating detailed information on how to design and construct flood-resistant buildings and structures.

Appropriate design and construction practices are necessary for any site development, including new and substantially improved structures. Requests for information on the construction requirements should be directed to the community. The State National Flood Insurance Program (NFIP) Coordinator and the appropriate FEMA Regional offices will also provide relevant information.

FEMA offers a wide array of material for land development professionals and designated communities regarding NFIP construction requirements in identified flood-prone areas. The following list is an overview of a number of FEMA materials related to flood-resistant design and construction.

\section{Online Resources Available from FEMA}

- Avoiding Flood Damage: A Checklist for Homeowners $<$ http://www.fema.gov/pdf/hazards/ flddam.pdf $>$

- Protecting Your Property from Flooding*

- Exterior Walls, $<$ http://www.fema.gov/fima/ how2003.shtm>

- Electrical System, $<$ http://www.fema.gov/fima/ how2004.shtm>

1. This document, IFAS publication DH0435, was published June 1998, revised May 2003. It is part of The Disaster Handbook, a component of the Comprehensive Disaster Preparedness and Recovery Education Module. For information about products and ordering, please visit: <http://disaster.ifas.ufl.edu>. All UF/IFAS Extension publications are available at the EDIS Web site: 〈http://edis.ifas.ufl.edu>.

2. Regina Fegan, student, Levin College of Law, University of Florida; and Michael T. Olexa, professor, Department of Food and Resource Economics, Institute of Food and Agricultural Sciences (IFAS), University of Florida, Gainesville, 32611.

Note: This publication is designed to provide accurate, current, and authoritative information on the subject. However, since the laws, regulations, administrative rulings, and court decisions on which it is based are subject to constant revision, portions of this publication could become outdated at any time. This publication is distributed with the understanding that the authors are not engaged in rendering legal advice or opinions, and the information contained herein should not be regarded, or relied upon, as a substitute for legal advice or opinion. For these reasons, the utilization of these materials by any person constitutes an agreement to hold harmless the authors, the Institute of Food and Agricultural Sciences and the University of Florida for any liability claims, damages or expenses that may be incurred by any person as a result of reference to or reliance on the information contained in this fact sheet.

The Institute of Food and Agricultural Sciences (IFAS) is an Equal Employment Opportunity - Affirmative Action Employer authorized to provide research, educational information and other services only to individuals and institutions that function without regard to race, creed, color, religion, age, disability, sex, sexual orientation, marital status, national origin, political opinions or affiliations. For information on obtaining other extension publications, contact your county Cooperative Extension Service office. Florida Cooperative Extension Service / Institute of Food and Agricultural Sciences / University of Florida / Larry R. Arrington, Interim Dean 
- Fuel Tanks, •

$<$ http://www.fema.gov/fima/

how2005.shtm>

- Heating, Ventilating, and Air Conditioning Equipment, $<$ http://www.fema.gov/fima/ how2006.shtm>

- Sewer Backflow Valves, <http://www.fema.gov/fima/ how2007.shtm>

- Above the Flood: Elevating Your Floodprone House, FEMA-347, <http://www.fema.gov/hazards/floods/ fema347.shtm>

- Protecting Building Utilities from Flood Damage, FEMA-348, <http://www.fema.gov/hazards/floods/pbuffd.shtm>

\section{Other Resources Available from FEMA}

To order these publications, call: 1-800-480-2520.

- Design Guidelines for Flood Damage Reduction, FEMA-15.

- Elevated Residential Structures, FEMA-54.

- Coastal Construction Manual, FEMA-55.

- Manufactured Home Installation in Flood Hazard Areas, FEMA-85

- Floodproofing Non-Residential Structures. FEMA-102.

- Retrofitting Flood-Prone Residential Structures, FEMA-114.

- Reducing Losses in High Risk Flood Hazard Areas: A Guide for Local Officials, FEMA-116.

- Answers and Questions About Substantially Damaged Buildings, FEMA-213.
- Repairing Your Flooded Home, FEMA-234.

- Mitigation of Flood and Erosion Damage to Residential Buildings in Coastal Areas, FEMA-257.

- Guide to Flood Maps. A how-to booklet for reading Flood Insurance Rate Maps (FIRMS), FEMA-258.

- Flood Emergency and Residential Repair Handbook, FIA-13.

- Engineering Principles and Practices for Retrofitting Flood Prone Residential Buildings, FEMA-259.

- Managing Floodplain Development in Approximate Zone A Areas: A Guide for Obtaining and Developing Base (100-year) Flood Elevations, FEMA-265

- Protecting Floodplain Resources, FEMA-268.

- Homeowner's Guide to Retrofitting: Six Ways to Protect Your House from Flooding, FEMA-312

*Note: FEMA is the Federal Emergency Management Agency, FIMA is the Flood Insurance and Mitigation Administration, a division of FEMA. 